\title{
Influence of Atmospheric Circulation on Glacier Mass Balance in Western Tibet: An Analysis Based on Observations and Modeling $\mathscr{O}$
}

\author{
Meilin Zhu, ${ }^{\mathrm{a}, \mathrm{b}}$ Lonnie G. Thompson, ${ }^{\mathrm{b}}$ Huabiao ZhaO,${ }^{\mathrm{a}, \mathrm{c}}$ Tandong YaO, ${ }^{\mathrm{a}}$ Wei Yang, ${ }^{\mathrm{a}}$ And ShengQiang Jin ${ }^{\mathrm{a}}$ \\ ${ }^{a}$ State Key Laboratory of Tibetan Plateau Earth System, Resources and Environment (TPESRE), Institute of Tibetan Plateau \\ Research, Chinese Academy of Sciences, Beijing, China \\ ${ }^{\mathrm{b}}$ Byrd Polar and Climate Research Center, The Ohio State University, Columbus, Ohio \\ ${ }^{\mathrm{c}}$ Ngari Station for Desert Environment Observation and Research, Institute of Tibetan Plateau Research, Chinese Academy of \\ Sciences, Tibet, China
}

(Manuscript received 20 December 2020, in final form 16 May 2021)

\begin{abstract}
Glacier changes on the Tibetan Plateau (TP) have been spatially heterogeneous in recent decades. The understanding of glacier mass changes in western Tibet, a transitional area between the monsoon-dominated region and the westerlies-dominated region, is still incomplete. For this study, we used an energy-mass balance model to reconstruct annual mass balances from October 1967 to September 2019 to explore the effects of local climate and large-scale atmospheric circulation on glacier mass changes in western Tibet. The results showed that Xiao Anglong Glacier is close to a balanced condition, with an average value of $-53 \pm 185 \mathrm{~mm}$ water equivalent (w.e.) $\mathrm{yr}^{-1}$ for $1968-2019$. The interannual mass balance variability during 1968-2019 was primary driven by ablation-season precipitation, which determined changes in the snow accumulation and strongly influenced melt processes. The interannual mass balance variability during 19682019 was less affected by ablation-season air temperature, which only weakly affected snowfall and melt energy. Further analysis suggests that the southward (or northward) shift of the westerlies caused low (or high) ablation-season precipitation, and therefore low (or high) annual mass balance for glaciers in western Tibet. In addition, the average mass balance for Xiao Anglong Glacier was $83 \pm 185,-210 \pm 185$, and $-10 \pm 185 \mathrm{~mm}$ w.e. $\mathrm{yr}^{-1}$ for 1968-90, 1991-2012, and 2013-19, respectively. These mass changes were associated with the variations in precipitation and air temperature during the ablation season on interdecadal time scales.
\end{abstract}

KEYWORDS: Glaciers; Atmospheric circulation; Precipitation; Climate variability; Energy budget/balance; Ice loss/ growth

\section{Introduction}

Glacier changes on the Tibetan Plateau (TP) over recent decades have been spatially heterogeneous: over most of the TP, glaciers have experienced accelerated shrinkage and mass loss (Maurer et al. 2019; Vincent et al. 2013; Yao et al. 2012; Zhao et al. 2016), while glaciers in the eastern Pamir, Karakoram, western Kunlun, and northern Qiangtang regions have exhibited long-term stability, or have even made slight mass gains (Bolch et al. 2017; Zhang et al. 2020; Zhu et al. 2018b). These changes to glacier mass balance are related to an increasing number of recent disasters on the TP (Gao et al. 2019; Yao et al. 2019), such as glacial lake outburst floods on the southeastern TP and in the Himalayas (Nie et al. 2018) and glacier collapse on the western TP (Tian et al. 2017). It is likely that the changes will also threaten the security of Asian water towers in the future (Immerzeel et al. 2020). Recognition of these risks in recent years has raised the importance of quantifying changes to glacier mass balance in different regions on the TP. However, changes to glacier mass

Supplemental information related to this paper is available at the Journals Online website: https://doi.org/10.1175/JCLI-D-200988.s1.

Corresponding authors: Meilin Zhu, meilinzhu@itpcas.ac.cn; Lonnie G. Thompson, thompson.3@osu.edu balance in western Tibet, a transitional area between the accelerating glacier mass loss in the western Himalayas and the longterm stability seen on the northern Qiangtang Plateau, and in the Karakoram-western Kunlun Mountains (Fig. S1 in the online supplemental material), remain unclear.

In addition, it is important to explore the mechanisms that control glacier mass changes across the TP, particularly the relationships between glaciers and climate drivers, so that future changes to Tibetan glaciers can be predicted. The drivers for temporal changes to glacier mass balance are different for different regions on the TP. Studies have shown that the recently increasing rates of decadal-scale glacier mass loss on the southeastern, central, and northeastern TP (Wang et al. 2010; Yao et al. 2012; Yang et al. 2016; Zhang et al. 2012) are mainly attributable to regional warming. In the western Himalayas, similar changes have been driven by increases in ablationseason (June-September) air temperature and by decreases in annual precipitation or winter precipitation (Azam et al. 2014; Zhao et al. 2016; Zhu et al. 2021). The recent decreases in the rate of mass loss for glaciers in eastern Pamir, on the northern Qiangtang Plateau, and in the western Kunlun Mountains, may be caused by increased annual or ablation-season precipitation (Fig. S1; Kääb et al. 2018; Zhang et al. 2020; Zhu et al. 2018b, 2020). It is necessary to study the drivers for temporal changes to glacier mass balance in western Tibet to improve our knowledge of the mechanisms determining the disparity in glacier behavior across the TP. 
The climate of the TP is primarily determined by the Indian summer monsoon (ISM), East Asian monsoon, and midlatitude westerlies (Tian et al. 2001; Yao et al. 2013). Atmospheric circulation has been found to influence glacier mass changes on the TP (Farinotti et al. 2020; Mölg et al. 2014; Yao et al. 2012). Earlier work has qualitatively explained the influence of atmospheric circulation on glacier mass change (Yao et al. 2012; Wagnon et al. 2013). Recent studies have tried to quantify the relationship between atmospheric circulation and glacier mass balance on the TP (Mölg et al. 2014; Yang et al. 2016; Zhu et al. 2018b). These studies have focused on glaciers in the westerliesdominated region or monsoon-dominated region. For example, Mölg et al. (2014) found that midlatitude westerlies in May and June drive interannual changes in glacier mass balance on the monsoon-dominated central TP. The TP can be divided into three climate regions using precipitation rate and seasonal variations in $\delta^{18} \mathrm{O}$ for precipitation: the monsoon-dominated region (south of $31^{\circ}-32^{\circ} \mathrm{N}$ ), the westerlies-dominated region (north of $34^{\circ}-35^{\circ} \mathrm{N}$ ), and the transitional area between these (Thompson et al. 2018; Tian et al. 2001; Yao et al. 2013). Atmospheric circulation that controls interannual changes in glacier mass balance in the transition region on the TP is still not well understood.

Long-term measurements of glacier mass balance and meteorology on the TP may help to quantify the effects of atmospheric circulation on glacier mass changes (Mölg et al. 2014; Yang et al. 2016; Zhang et al. 2021; Zhu et al. 2018b, 2021). However, ongoing measurements of mass balance on the TP are only made for Xiao Dongkemadi Glacier. To address this, in situ high-altitude meteorological and glaciological observations and an energy-mass balance (EMB) model have been successfully used to reconstruct worldwide glacier mass balance over the last several decades (Möller et al. 2016; Rupper and Roe 2008; Van Pelt et al. 2019; Yang et al. 2016; Zhu et al. 2018b), and this can be used to quantify the influence of climate drivers on glacier mass changes, from an energy balance perspective (Mölg et al. 2014; Zhu et al. 2018a).

Xiao Anglong Glacier, in western Tibet, is within the area of transition between the westerlies- and monsoon-dominated climate regimes, and is influenced by midlatitude westerlies in the winter and spring, and jointly influenced by midlatitude westerlies and the ISM in summer (Fig. 1a) (Tian et al. 2001; Yao et al. 2013; Thompson et al. 2018). A meteorological and glaciological monitoring campaign has been established. Shiquanhe meteorological station $\left[32^{\circ} 30^{\prime} \mathrm{N}, 80^{\circ} 5^{\prime} \mathrm{E}, 4278.6 \mathrm{~m}\right.$ above mean sea level (MSL)], approximately $83 \mathrm{~km}$ from Xiao Anglong Glacier $\left(32^{\circ} 51^{\prime} 36^{\prime \prime} \mathrm{N}, 80^{\circ} 54^{\prime} 0^{\prime \prime} \mathrm{E}\right.$; Randolph Glacier Inventory ID: RGI60-14.25559; Fig. 1a), provides a long time series of meteorological data. Xiao Anglong Glacier is a typical glacier for this region, and so these measurements can be used to understand the influence of interactions between the monsoon and midlatitude westerlies on temporal mass balance patterns. The objectives of this study are 1) to reconstruct a time series of mass balance for Xiao Anglong Glacier during 1968-2019 (from 1 October 1967 to 30 September 2019) and 2) to discuss the possible influence of macroscale atmospheric circulation on changes to mass balance for glaciers in western Tibet.

\section{Study area, data, and method}

\section{a. Study area and meteorological conditions}

Xiao Anglong Glacier is a typical valley-type and continental glacier (Shi and Liu 2000), located in western Tibet (Fig. 1a). It had an altitude range of 5769-6467 m MSL (Fig. 1b). The glacier area decreased from $1.58 \mathrm{~km}^{2}$ in November 2001 to $1.5 \mathrm{~km}^{2}$ in November 2015 (Chen et al. 2021). Two automatic weather stations (AWSs) were installed near Xiao Anglong Glacier (Fig. 1b). AWS1 was established at $5141 \mathrm{~m}$ MSL $\left(32^{\circ} 54^{\prime} 38.14^{\prime \prime} \mathrm{N}, 80^{\circ} 50^{\prime} 13.58^{\prime \prime} \mathrm{E}\right)$ in August 2014, approximately $7.5 \mathrm{~km}$ northeast of Xiao Anglong Glacier. AWS2 was established at $5638 \mathrm{~m} \mathrm{MSL}\left(32^{\circ} 52^{\prime} 4.80^{\prime \prime} \mathrm{N}, 80^{\circ} 55^{\prime} 0.80^{\prime \prime} \mathrm{E}\right)$ in August 2015, and is approximately $1.4 \mathrm{~km}$ northwest of Xiao Anglong Glacier. Both AWSs record meteorological variables every half hour, including air temperature $\left(T_{a}\right)$, relative humidity (RH), wind speed (WS) and wind direction (WD), downward and upward shortwave radiation $\left(S_{\text {in }} / S_{\text {out }}\right.$, respectively), incoming and outgoing longwave radiation $\left(L_{\text {in }} / L_{\text {out }}\right.$, respectively), and precipitation. Precipitation was obtained from all-weather precipitation gauges (T-200B), which were equipped with hanging weighing transducers. Details of the instruments used to measure meteorological observations are listed in Table S1 in the online supplemental material. There were some gaps for each day in the data recorded for $T_{a}$ and $\mathrm{RH}$ at AWS2, and we therefore mainly used meteorological data from AWS1 in this work.

An overview of the meteorological conditions recorded at AWS1 from 1 October 2014 to 30 September 2019 is provided (Fig. 2). The daily mean $T_{a}$ fluctuated between $-23.5^{\circ}$ and $11.6^{\circ} \mathrm{C}$, and the mean annual $T_{a}$ was $-4.4^{\circ} \mathrm{C}$ (Fig. 2a). The mean monthly $T_{a}$ varied from minimum of $-15.9^{\circ} \mathrm{C}$ in January to maximum of $6.6^{\circ} \mathrm{C}$ in July and August (Fig. 2b). The daily mean RH ranged from $5.7 \%$ to $99 \%$ (Fig. 2c). The highest mean monthly RH was in July and August, and the lowest RH was observed in November (Fig. 2d). The daily mean WS presented significant interdaily fluctuations and reached a maximum of $12.6 \mathrm{~m} \mathrm{~s}^{-1}$ in the winter (Fig. 2e). The lowest mean monthly WS was $3.6 \mathrm{~ms}^{-1}$, which occurred in June (Fig. 2f). There were 367 precipitation events from 1 October 2014 to 30 September 2019 . The daily precipitation amount was mostly less than $5 \mathrm{~mm}$, and it exceeded $10 \mathrm{~mm}$ on 23 days during this period (Fig. $2 \mathrm{~g}$ ). There was a strong peak in monthly precipitation for July-August (Fig. 2h). The mean annual precipitation was $224 \mathrm{~mm}$, and $86.3 \%$ of the total annual precipitation occurred in the ablation season, indicating that Xiao Anglong Glacier is a summer-accumulation type glacier (Sakai et al. 2015). There were significant interdaily fluctuations in the daily mean $S_{\text {in }}$ due to the influence of clouds (Fig. 2i). The mean monthly $S_{\text {in }}$ was greatest in June and smallest in December (Fig. 2j). The mean $S_{\text {in }}$ was 284 and $224 \mathrm{~W} \mathrm{~m}^{-2}$ in the ablation season and cold season (October-May), respectively.

\section{b. Mass balance measurements}

Measurements of the mass balance have been made using the glaciological method (Cuffey and Paterson 2010) on Xiao Anglong Glacier since 2014 (Fig. 1c). The stakes are located 


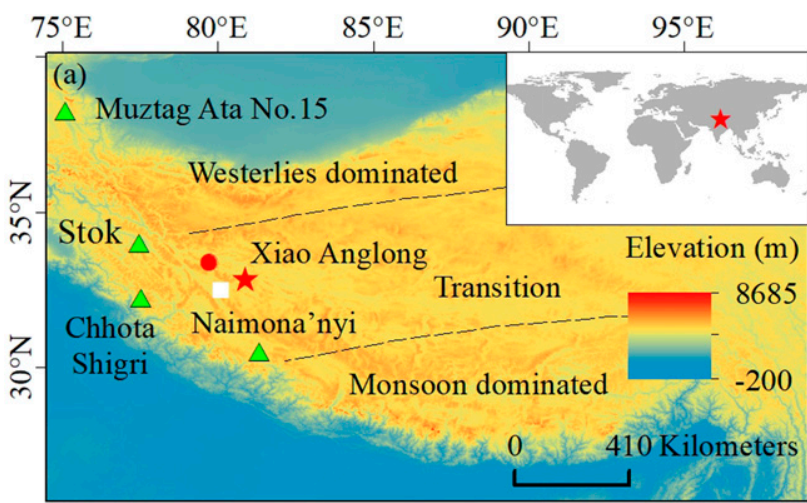

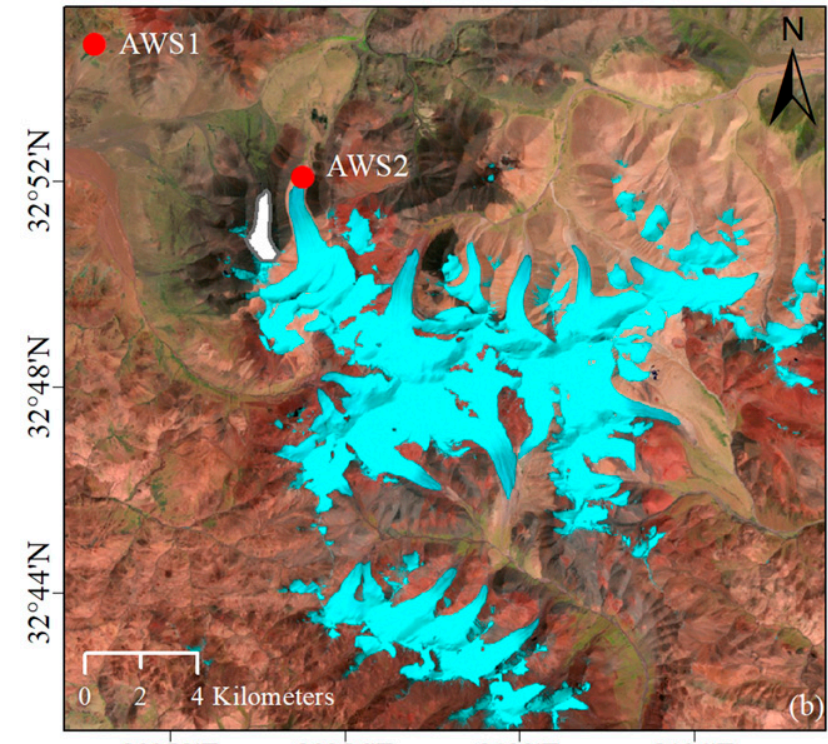

$80^{\circ} 52^{\prime} \mathrm{E} \quad 80^{\circ} 56^{\prime} \mathrm{E}$ $81^{\circ} 0^{\prime} \mathrm{E}$ $81^{\circ} 4^{\prime} \mathrm{E}$

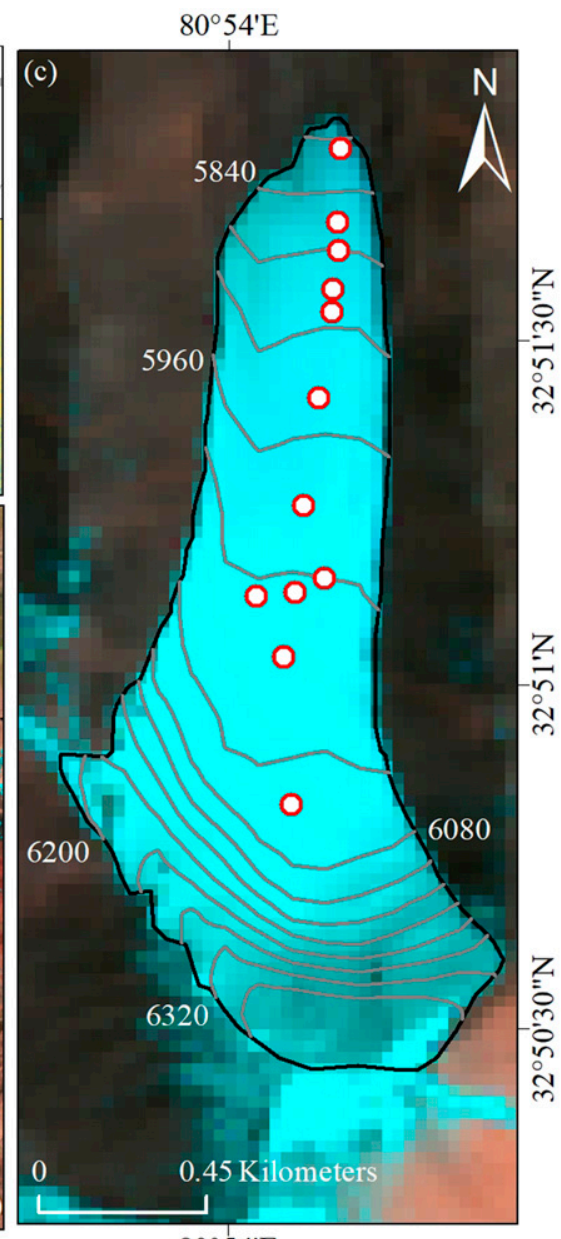

$80^{\circ} 54^{\prime} \mathrm{E}$

FIG. 1. (a) Locations of Xiao Anglong Glacier (red star), four other glaciers near Xiao Anglong Glacier (green triangles), Shiquanhe meteorological station (white square), and Ngari Station for Desert Environment Observation and Research (red circle). Based on Tian et al. (2001), Yao et al. (2013), and Thompson et al. (2018), the black dashed lines separate the TP as three major climate regimes: a monsoon-dominated region, a westerliesdominated region, and their transitional region. The rectangle in the inset box shows the location of Xiao Anglong Glacier (red star) from a global perspective. (b) The locations of two AWSs (red circle) and all the glaciers in the Anglong region. Glacier outlines in the Anglong region were obtained from the Randolph Glacier Inventory version 6. Glaciers are marked by cyan color and Xiao Anglong Glacier is marked by white color. (c) A contour map with the distribution of measuring stakes in October 2018 on Xiao Anglong Glacier (white dots). The black and gray lines in map (c) indicate the boundary and the contour line of Xiao Anglong Glacier, respectively. Satellite images in maps (b) and (c) are taken from Landsat 8 Operational Land Imager (OLI) on 3 Sep 2016.

between 5750 and $6060 \mathrm{~m}$ MSL. The glacier is inaccessible above $6100 \mathrm{~m}$ MSL and these higher altitudes are not surveyed. When there was snow cover near the stake, a snow pit was dug to measure snow layer density and stratigraphy. The heights of the individual stakes and snow layer density and stratigraphy taken from snow pits are manually recorded. The point mass balance value at the middle altitude at each individual interval (which is calculated by the interpolation and extrapolation of the point mass balance at stakes) is multiplied by the area of each individual interval (40-m elevation bands), the values from each different zone were added together, and the total for that value was divided by the total glacier surface area to obtain the glacier-wide mass balance (Zhu et al. 2021). The uncertainty for the glaciological glacier-wide mass balance stems mainly from uncertainties in the point measurements of ablation and accumulation (such as the stake readings, the representativeness of the point measurements, and the observed snow depth and density), and the calculation method used to obtain the glacier-wide mass balance (Cogley 2005; Kenzhebaev et al. 2017; Thibert et al. 2008). The uncertainties in point measurements of ablation $[ \pm 100 \mathrm{~mm}$ water equivalent (w.e.) $\mathrm{yr}^{-1}$ ] were defined as the standard deviation of these differences between the stakes at the same altitude in different altitudes of the ablation zone on Xiao Anglong Glacier. Considering the uncertainties in density and snow depth measurement, the uncertainty in point measurements of accumulation 


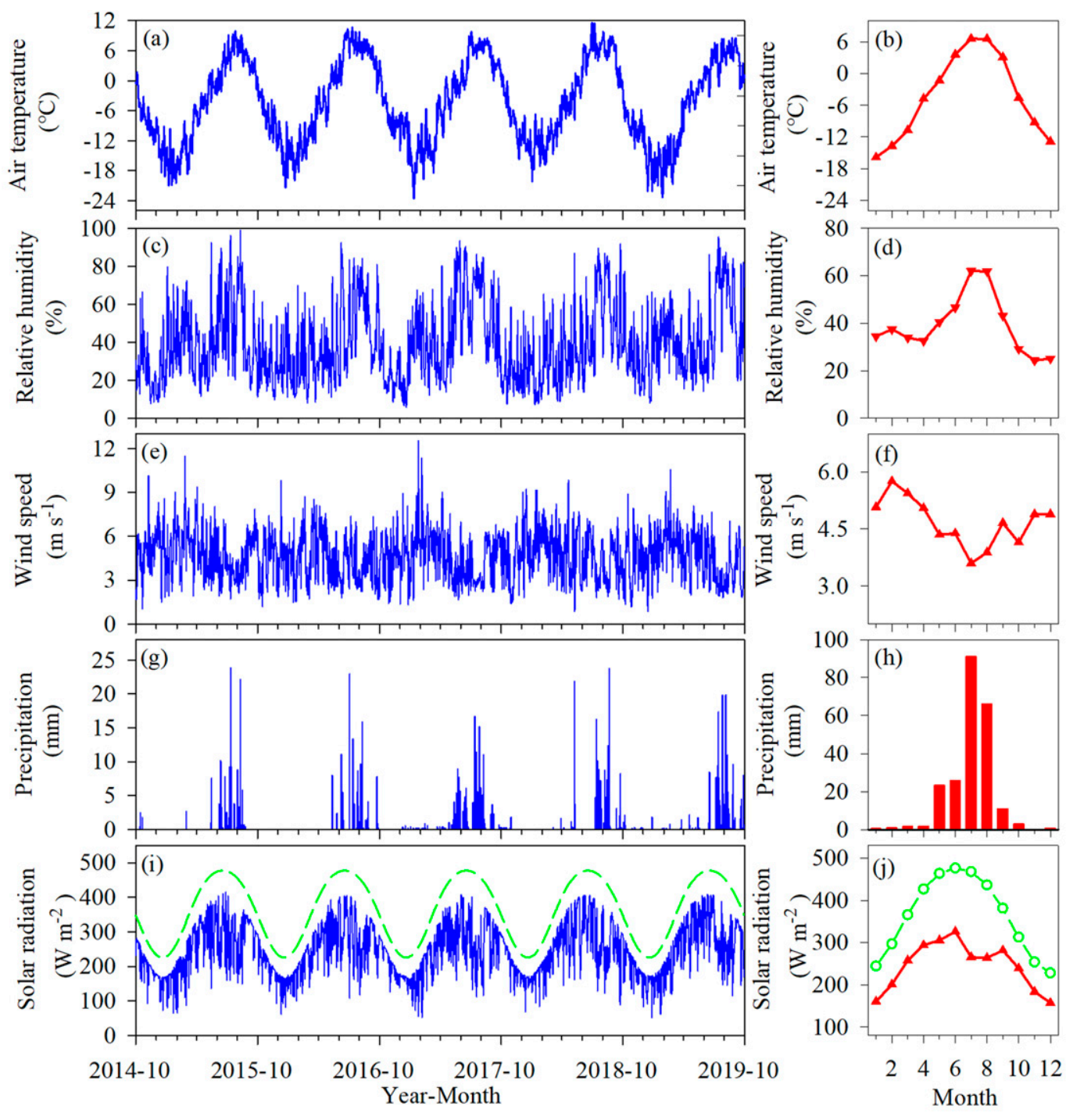

FIG. 2. Daily values of (a) air temperature, (c) relative humidity, (e) wind speed, (g) precipitation, and (i) incoming shortwave radiation at AWS1 site. The dashed green line in Fig. $2 \mathrm{i}$ indicates the calculated daily mean solar radiation at the top of the atmosphere. The mean monthly values of (b) $2-\mathrm{m}$ air temperature, (d) relative humidity, (f) wind speed, (h) precipitation, and (j) incoming shortwave radiation at the AWS1 site. The green line in (j) indicates the calculated mean monthly solar radiation at the top of the atmosphere.

was $\pm 130 \mathrm{~mm}$ w.e. $\mathrm{yr}^{-1}$, which was adopted from Thibert et al. (2008). The uncertainties in extrapolation for the ablation area $\left( \pm 120 \mathrm{~mm}\right.$ w.e. $\left.\mathrm{yr}^{-1}\right)$ and accumulation area $( \pm 180 \mathrm{~mm}$ w.e. $\mathrm{yr}^{-1}$ ) were obtained from Kenzhebaev et al. (2017). Thus, the total uncertainty for measured annual glacier-wide mass balance was $\pm 270 \mathrm{~mm}$ w.e. $\mathrm{yr}^{-1}$ after adding all the parametric uncertainties using the error propagation law.

Each year, around 12-15 monitoring stakes were drilled into the ice, distributed across the entire glacier surface (Fig. 1b). Some stakes were lost due to snow cover, or were damaged by animals, and some measurements failed due to extremely bad weather. Stakes over the glacier surface were always measured at the end of each ablation season (June-September) during the 2015-19 period, except 2017/18. For 2017/18, we only calculated the glacier-wide mass balance from October 2017 to June 2018. In addition, only four stakes were available for 2016/ 17 , and so it was difficult to calculate glacier-wide mass balance for that balance year. The balance year is from 1 October to 30 September of the next year. The 2016/17 stake measurements were used to calibrate the energy-mass balance model, and the glacier-wide mass balance for that year can be replaced with a value from precise differential GPS (DGPS) measurements. The glacier-wide mass balance was $62,-462,-135$, and $267 \mathrm{~mm}$ w.e. for 2014/15, 2015/16, 2017/18 (October 2017 to June 2018), and 2018/19, respectively. Glacier surface change was measured by Starfire E3050 (or E3040) DGPS over the period 2015-18 (Fig. S2). According to the DGPS measurements, the average thickness change was $0.031,-0.632$, and 
$0.057 \mathrm{~m}$ in 2014/15, 2015/16, and 2016/17, respectively. To make comparisons straightforward, we converted the measurements of the glacier-thinning rate to water equivalent units, using an ice density of $900 \mathrm{~kg} \mathrm{~m}^{-3}$, which gave glacier-wide mass balances of $28,-569$, and $51 \mathrm{~mm}$ w.e. for $2014 / 15,2015 / 16$, and 2016/17, respectively. The two methods used to calculate the annual glacier-wide mass balances gave similar results.

\section{c. Other data}

To consider changes over a longer time series (52 years), we used monthly air temperature and total precipitation from the Climatic Research Unit dataset (CRU TS v. 4.04; $0.5^{\circ} \times 0.5^{\circ}$; 1901-2019) (Harris et al. 2020), and the monthly geopotential height and wind fields from the Japanese 55-Year Reanalysis dataset (JRA-55; $1.25^{\circ} \times 1.25^{\circ}$; 1958-2019) (Kobayashi et al. 2015) to assess the influence of macroscale atmospheric circulation on glacier mass changes.

\section{d. The energy and mass balance model}

The EMB model used in this study is described in detail in Fujita and Ageta (2000) and Yang et al. (2013). Here we mainly present the most important features of the EMB model. The model solves the following equation:

$$
M=\int\left(\frac{Q_{M}}{L_{m}}+\frac{H_{\mathrm{lat}}}{L_{v}}+C_{\mathrm{en}}+P_{\text {snow }}\right) d t,
$$

where point mass balance $M$ is composed of the melt, sublimation/evaporation, refreezing $C_{\mathrm{en}}$, and solid precipitation $P_{\text {snow }} ; P_{\text {snow }}$ is calculated by daily precipitation and two critical air temperature $T_{a}$ thresholds for rain $T_{\text {rain }}$ and snow $T_{\text {snow }}$ (Yang et al. 2013). Also, $L_{m}$ is the latent heat of ice melt and $L_{v}$ is the latent heat of evaporation/sublimation. Melt energy $Q_{M}$ is calculated using the surface energy balance equation:

$$
Q_{M}=S_{\text {in }}(1-\alpha)+L_{\text {in }}+L_{\text {out }}+H_{\text {sen }}+H_{\text {lat }}+Q_{G},
$$

where albedo $\alpha$ is parameterized according to the method suggested by Oerlemans and Knap (1998) and Mölg et al. (2008). The term $L_{\text {in }}$ was calculated using the parameterization of the clear-sky atmospheric emissivity of Brunt (1932) combined with cloud correction of Crawford and Duchon (1999) and its parameters were calibrated using the measured $L_{\text {in }}$ at AWS1 (Fig. S3). The term $L_{\text {out }}$ was computed by the StefanBoltzmann law from surface temperature $\left(T_{S}\right)$, which can be obtained using the same iterative calculations of Fujita and Ageta (2000). Sensible heat flux $\left(H_{\text {sen }}\right)$ and latent heat flux $\left(H_{\text {lat }}\right)$ are modeled using the bulk method (Fujita and Ageta 2000). Subsurface heat flux $\left(Q_{G}\right)$ and $C_{\text {en }}$ are calculated using the method from Fujita and Ageta (2000); $Q_{M}$ is defined as positive when it is larger than 0 , and the other fluxes are defined as positive when they are directed toward the surface.

The model inputs included the reconstructed long-term daily mean for $T_{a}, \mathrm{RH}, S_{\mathrm{in}}, \mathrm{WS}$, and total daily precipitation, as well as the gradients for these, and the glacier area in each elevation band. To obtain meteorological forcing data from 1 October 1962 to 30 September 2019 at AWS1 site, the data from Shiquanhe meteorological station (http://data.cma.cn/) were used. Time series of daily mean $T_{a}$, WS, RH, and $S_{\text {in }}$ were constructed using a linear regression relationship that was established between the Shiquanhe meteorological station data and the available AWS1 data for each month. Daily $S_{\text {in }}$ at Shiquanhe meteorological station was estimated from the recorded sunshine duration, $\mathrm{RH}, T_{a}$, air pressure, and geographical information (latitude, longitude, and altitude), using the model proposed by Yang et al. (2010). The reconstructed data and the observed meteorological variables are compared in Fig. S4. Daily precipitation from 1 October 1967 to 30 September 2019 at AWS1 site was reconstructed by applying a scaling factor of 1.9 to the total daily precipitation amount recorded at Shiquanhe meteorological station, following the method in Mölg et al. (2012). The cumulative precipitation amount, monthly precipitation, and annual precipitation were used to justify the reliability of the reconstructed precipitation time series (Fig. S5). Above all, the reconstructed and measured meteorological data at AWS1 near the glacier show good correlations on different time scales. Also, Chen et al. (2016) used highresolution, long-term satellite observations to evaluate the spatial scales of the climate variations across the TP. They found that the annual surface temperature had typical spatial scales of $302-480 \mathrm{~km}$, while the annual precipitation showed smaller scales of $111-182 \mathrm{~km}$. Thus, the reconstructed meteorological data at Shiquanhe meteorological station are reliable to drive the EMB model in this work. The daily mean WS was assumed to be independent of altitude. Data from AWS1, and from Shiquanhe meteorological station, were used to determine the gradient of $T_{a}$ and $\mathrm{RH}$ in the ablation season and in the cold season. The gradient for $S_{\text {in }}$ was calculated from data at AWS1 and at AWS2.

Temporal changes in the glacier area are taken into account in the model by using different boundaries for Xiao Anglong Glacier for different years, as retrieved from Landsat satellite images. These boundaries referenced in the data in Ye et al. (2017). Cloud-free images from Landsat Multispectral Scanner (MSS) in 1977, Landsat Thematic Mapper (TM) in 1992, Landsat 7 Enhanced Thematic Mapper (ETM) in 1999, Landsat 7 ETM in 2011, and Landsat 8 Operational Land Imager (OLI) in 2018 were selected to represent the glacier boundary between 1962 and 1985, between 1986 and 1996, between 1997 and 2005, between 2006 and 2015, and between 2016 and 2019, respectively. The glacier area distribution at each elevation band is derived from the Landsat-derived glacier boundaries and the 90-m Shuttle Radar Topography Mission (SRTM) digital elevation model (DEM) (https://glovis.usgs.gov/).

These data were used to drive the EMB model for each 40-m interval (which is similar to the elevation band in calculating glacier-wide mass balance from observed point mass balance at stakes) over the altitudinal range of the glacier. In our work, most physical parameters used in the EMB model were taken from measurements or published data. Only the parameter values required by albedo model, and the precipitation gradient $P_{\text {rate }}$, were adjusted to achieve the best agreement between the modeled values and the in situ measurements of the annual mass balances (the glacier-wide mass balances and the point 

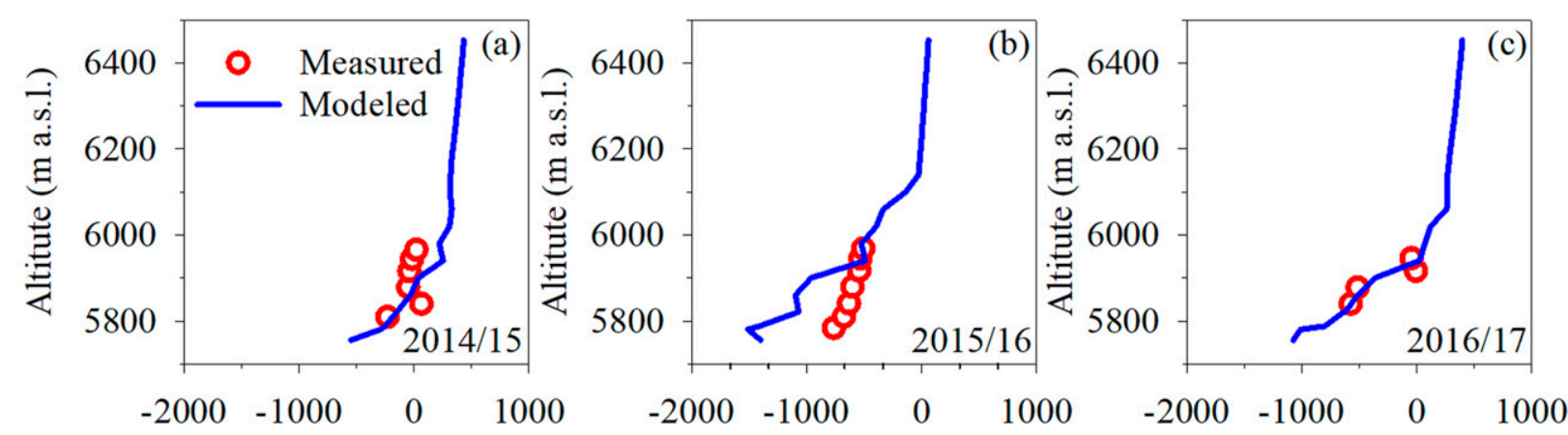

Mass balance (mm w.e.)

Mass balance (mm w.e.)
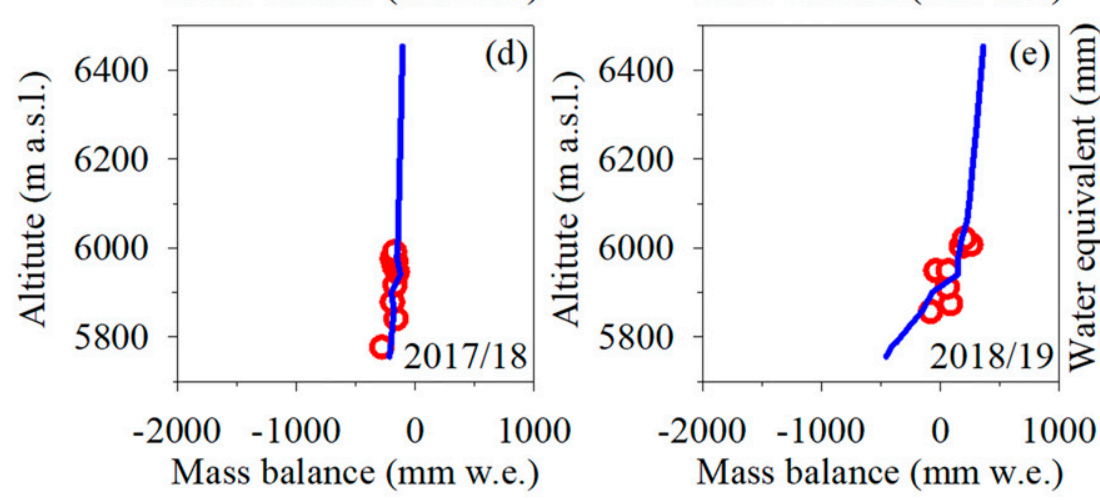

Mass balance (mm w.e.)

FIG. 3. (a)-(e) Comparison of modeled (blue line) and measured (red circle) point mass balances at different altitudes in different years, and (f) modeled and measured glacier-wide mass balance with their uncertainties in different years on Xiao Anglong Glacier.

mass balances). Point mass balances at stakes and glacier-wide mass balances were all calculated using parameter values for the albedo model taken from Yang et al. (2013), and a precipitation gradient of $12 \% 100 \mathrm{~m}^{-1}$, which was calculated from the annual precipitation measurements made at AWS1 and at Shiquanhe meteorological station from 2014 to 2019. These modeled mass balances were larger than the measured values. Next, the mass balances were recalculated by incrementally decreasing $P_{\text {rate }}$ by 0.01 to reduce the differences between in situ measured and modeled annual glacier-wide mass balances and point mass balances at different altitudes. We then adjusted a parameter for ice albedo (ice_a) slightly to minimize the differences between the measured and modeled annual glacier-wide mass balances and point mass balances at different altitudes. All the parameters used in this work are listed in Table S2.

\section{e. Model calibration, validation, and uncertainty analysis}

The point mass balances that were measured for Xiao Anglong Glacier increased gradually with increasing altitude, and varied from -760 to $205 \mathrm{~mm}$ w.e. during the period 2015 19 (Fig. 3). The vertical gradients for the annual mass balance were $1.5,1.25$, and $1.85 \mathrm{~mm}$ w.e. $\mathrm{m}^{-1}$ in $2014 / 15,2015 / 16$, and 2018/19, respectively. Figure 3 compares the modeled and measured annual mass balances for 2015-19, as a function of elevation. The simulated results largely agree with the in situ observations of mass balance, except for a discernible underestimation below $5900 \mathrm{~m}$ MSL during 2015/16. We found that the reconstructed precipitation amount and frequency were anomalously low in May and June 2016 (Fig. S5b), which reduced the simulated albedo, and enhanced the modeled glacier melt and mass loss in summer 2016. The rootmean-square error (RMSE) and correlation coefficient $(r)$ between the measured and simulated values at all the stakes were $214 \mathrm{~mm}$ w.e. and 0.88 respectively for $2015-19$. Figure $3 \mathrm{f}$ shows good agreement between the modeled and measured annual glacier-wide mass balances, with a correlation coefficient of 0.91 and a RMSE of $131 \mathrm{~mm}$ w.e. $\mathrm{yr}^{-1}$. Using the available submeter commercial stereo imagery, Shean et al. (2020) estimated an average mass balance of $15 \pm 198 \mathrm{~mm}^{\text {w.e. }} \mathrm{yr}^{-1}$ for Xiao Anglong Glacier between 2000 and 2018. Our modeled value ( $-162 \pm 185 \mathrm{~mm}$ w.e.) for the same period lies within the uncertainties of the value presented in Shean et al. (2020). This agreement demonstrates that the calibrated EMB model is a suitable tool for evaluating changes in mass balance and their relationship with climate drivers.

The uncertainties for parameters in the albedo model, and for the precipitation gradient, are unknown, and therefore these parameters were changed by $\pm 10 \%$ from their original/calibrated values to estimate the parametric uncertainty in the glacier mass balance model (Anslow et al. 2008; Ragettli et al. 2013; Zhu et al. 2021). The highest bulk coefficient $\left(C_{d}\right)$ for the sensible and latent heat was 0.0038 and the lowest phase threshold for rain $\left(T_{\text {rain }}\right)$ was $-0.5^{\circ} \mathrm{C}$ (Yang et al. 2013). Considering the differences between the values for these parameters in this work and in Yang et al. (2013), the uncertainties for $C_{d}$ and 
TABLE 1. Mean seasonal values of meteorological variables, glacier-wide mass balance components, and glacier-wide energy balance components for 1968-2019. The values in parentheses are the standard deviations of detrending variables.

\begin{tabular}{|c|c|c|c|}
\hline \multirow[b]{2}{*}{ Variables } & \multicolumn{3}{|c|}{ 1968-2019 } \\
\hline & Cold & Ablation & Annual \\
\hline$T_{a}\left({ }^{\circ} \mathrm{C}\right)$ & -10.9 & 4.2 & -5.9 \\
\hline$P(\mathrm{~mm})$ & 24.4 & 125.5 & 149.9 \\
\hline Snowfall (mm w.e.) & $47(25)$ & $240(111)$ & $287(117)$ \\
\hline Refreezing (mm w.e.) & $1(1)$ & $73(28)$ & $74(28)$ \\
\hline Sublimation (mm w.e.) & $-98(17)$ & $-79(17)$ & $-177(23)$ \\
\hline Melt (mm w.e.) & $0(0)$ & $-237(144)$ & $-237(144)$ \\
\hline Mass balance (mm w.e.) & $-50(33)$ & $-3(208)$ & $-53(208)$ \\
\hline Rain (mm) & 0 & 1 & 1 \\
\hline$S_{\text {in }}\left(\mathrm{W} \mathrm{m}^{-2}\right)$ & $251(3)$ & $312(8)$ & $271(4)$ \\
\hline Albedo & 0.74 & 0.72 & 0.73 \\
\hline$S_{\text {out }}\left(\mathrm{W} \mathrm{m}^{-2}\right)$ & $-186(8)$ & $-226(8)$ & $-199(5)$ \\
\hline$S_{\text {net }}\left(\mathrm{W} \mathrm{m}^{-2}\right)$ & $65(8)$ & $86(11)$ & $72(6)$ \\
\hline$L_{\mathrm{in}}\left(\mathrm{W} \mathrm{m}^{-2}\right)$ & $164(2)$ & $234(4)$ & $187(2)$ \\
\hline$L_{\text {out }}\left(\mathrm{W} \mathrm{m}^{-2}\right)$ & $-235(3)$ & $-295(3)$ & $-255(3)$ \\
\hline$L_{\text {net }}\left(\mathrm{W} \mathrm{m}^{-2}\right)$ & $-71(3)$ & $-61(3)$ & $-68(2)$ \\
\hline$H_{\mathrm{sen}}\left(\mathrm{W} \mathrm{m}^{-2}\right)$ & $14(5)$ & $4(2)$ & $11(3)$ \\
\hline$H_{\text {lat }}\left(\mathrm{W} \mathrm{m}^{-2}\right)$ & $-13(2)$ & $-21(4)$ & $-16(2)$ \\
\hline$Q_{G}\left(\mathrm{~W} \mathrm{~m}^{-2}\right)$ & $4(2)$ & $-1(1)$ & $3(1)$ \\
\hline$Q_{M}\left(\mathrm{~W} \mathrm{~m}^{-2}\right)$ & $0(0)$ & $7(5)$ & $2(2)$ \\
\hline
\end{tabular}

$T_{\text {ain }}$ were set to 0.0018 and $0.5^{\circ} \mathrm{C}$, respectively (Table S3). We also set the uncertainty of the phase threshold for snow $\left(T_{\text {snow }}\right)$ to $0.5^{\circ} \mathrm{C}$. We found that the parameters to which the model was most sensitive were the fresh snow albedo $\left(a_{\text {snow }}\right)$ and the firn albedo $\left(a_{\text {firn }}\right)$ in the albedo model (Table S3). The sensitivity of the mass balance to other parameters was smaller than $70 \mathrm{~mm}$ w.e. $\mathrm{yr}^{-1}$. The total uncertainty in the modeled annual glacier-wide mass balance was estimated by adding all the parametric uncertainties, using error propagation law, as suggested by Azam and Srivastava (2020) and Zhu et al. (2021), to give a total uncertainty of $185 \mathrm{~mm}$ w.e. $\mathrm{yr}^{-1}$ for the modeled glacier-wide mass balance.

\section{Results}

\section{a. The glacier-wide energy balance components}

Net shortwave radiation $\left(S_{\text {net }}\right)$ was the largest source of incoming energy, and net longwave radiation $\left(L_{\text {net }}\right)$ was the largest energy sink throughout the year (Table 1). Interannual changes in $S_{\text {net }}$ were controlled by albedo, with a correlation coefficient of $-0.98(p<0.01)$ for the ablation season, and of $-0.99(p<0.01)$ for the cold season. In the ablation season, interannual changes in $L_{\text {net }}$ were controlled by $L_{\text {in }}(r=0.72$, $p<0.01$ after detrending); for the cold season, interannual changes in $L_{\text {net }}$ were controlled by $L_{\text {out }}(r=0.75, p<0.01$ after detrending). It was found that $H_{\text {lat }}$ was an important energy sink through evaporation or sublimation processes, which reduced the incoming energy that was available for glacier melt. For the ablation season, the absolute values for $H_{\text {sen }}$ and $Q_{G}$ were small (Table 1$)$. The melt mainly occurred in the ablation season (Table 1). The interannual variability of $Q_{M}$ in the ablation season was controlled by variations in ablation-season albedo or $S_{\text {out }}$. This is because the standard deviations of $S_{\text {out }}$ (or $S_{\text {net }}$ ) and $S_{\text {in }}$ were significantly larger than those of the other energy balance components for the ablation season (Table 1), and because the correlations between $S_{\text {out }}$ and $Q_{M}(r=-0.64$, $p<0.01$ after detrending) and between albedo and $Q_{M}$ ( $r=-0.68, p<0.01$ after detrending) were significant, while the correlations between $S_{\text {in }}$ and $Q_{M}(r=0.31, p<0.05$ after detrending) were weak for the ablation season. Above all, the energy balance during both the ablation and cold seasons was largely controlled by $S_{\text {net }}, L_{\text {net }}$, and $H_{\text {lat }}$, and interannual changes in $Q_{M}$ in the ablation season were mainly driven by variations in albedo.

\section{b. Seasonal glacier-wide mass balance components and mass balance sensitivity}

The mean annual mass balance during 1968-2019 was $-53 \pm$ $185 \mathrm{~mm}$ w.e. $\mathrm{yr}^{-1}$, which shows that the glacier was close to a balanced condition. The total glacier area in the Anglong region reduced from $125 \mathrm{~km}^{2}$ in 1976 to $110 \mathrm{~km}^{2}$ in 2014 , and the mean retreat rate was $0.39 \mathrm{~km}^{2} \mathrm{yr}^{-1}$, or $0.31 \% \mathrm{yr}^{-1}$ (Ye et al. 2017). In addition, our modeled values show that mean mass balance during 1968-99 was $150 \pm 185 \mathrm{~mm}$ w.e. $\mathrm{yr}^{-1}$ higher than that during 2000-19 for Xiao Anglong Glacier. The fluctuations in glacier mass balance through the years are mainly due to temperature and precipitation (Oerlemans 2005). The similar climate changes can cause the similar changes in mass balance for glacier in the same region. Thus, the mean glacier mass balance in the Anglong region during 1968-99 can be higher than $-80 \pm 120 \mathrm{~mm}$ w.e. $\mathrm{yr}^{-1}$ (Shean et al. 2020), which is the mean mass balance of the 113 glaciers in the Anglong region for 2000-18. Above all, these numbers all show that glaciers in the Anglong region were close to a balanced condition during 1968-2019.

The mass balance in the cold season was dominated by low snowfall and sublimation (Table 1). The mass balance components were significantly larger in the ablation season than in the cold season. About $31 \%$ of annual melt was refrozen in the snowpack. In all, $83.6 \%$ of annual snowfall occurred in the ablation season, and ablation-season snowfall amount was similar to the amount of melt during the ablation season. Mass loss from sublimation and/or evaporation was about 3 times smaller than mass loss from melt in the ablation season (Table 1). Thus, a similar amount of snowfall and melt in the ablation season resulted in a small mass balance in the ablation season, and for the whole year.

It is also important to understand glacier mass balance sensitivity to climate, so that the response of glacier mass balance to climate change can be anticipated. The sensitivity of the mass balance of Xiao Anglong Glacier to changes in air temperature was $205 \mathrm{~mm}$ w.e. $\mathrm{yr}^{-1}{ }^{\circ} \mathrm{C}^{-1}$, and to changes in precipitation, it was $62 \mathrm{~mm}$ w.e. $\mathrm{yr}^{-1}(10 \%)^{-1}$. These sensitivities are similar to those found for Muztag Ata No. 15 Glacier, which have experienced low mass loss over recent years (Zhu et al. 2018a). Both sensitivities are significantly lower than those found for Chhota Shigri (Azam et al. 2014), Stok (Soheb et al. 2020), and Naimona'nyi (Zhu et al. 2021) glaciers in the western Himalayas, which have experienced greater mass loss over recent years. 

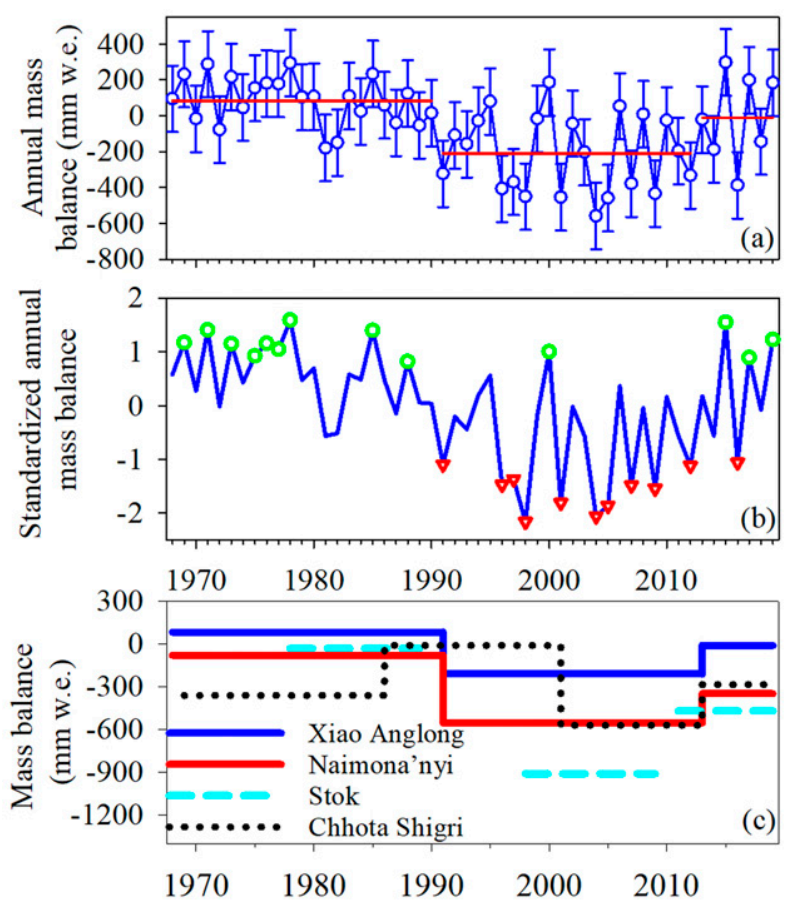

FIG. 4. (a) Temporal variation in the simulated annual mass balance for Xiao Anglong Glacier for 1968-2019. The horizontal line indicated the average mass balance for three different periods. The error bars represent the possible uncertainty of the modeled mass balance. (b) The time series of the standardized ablationseason mass balance for Xiao Anglong Glacier during 1968-2019. Symbols highlight distinctly positive mass balance phases (green circles; 20.75 ) and negative mass balance phases (red inverted triangle; $\leq-0.75$ ). (c) The decadal average mass balance during the last several decades for different glaciers. The mass balances for Naimona'nyi Glacier were from modeled values in Zhao et al. (2016) during 1970-2004 and in 2006/07, and from in situ measurements during 2004-19 (Zhu et al. 2021); the mass balances for Chhota Shigri Glacier were from modeled results in Azam et al. (2014) during 1970-2012, and from in situ measurements in Mandal et al. (2020) during 2013-19; and the mass balances for Stok Glacier were from modeled values in Soheb et al. (2020) during 1979-2019. The year on the $x$ axis indicates the balance year.

\section{c. The interannual and interdecadal changes in the mass balance components}

The annual mass balances show large interannual variations, from $-559 \mathrm{~mm}$ w.e. in $2003 / 04$ to $297 \mathrm{~mm}$ w.e. in $2014 / 15$ (Fig. 4a). The interannual changes (or standard deviations) in each mass balance component were similar for the ablation season and for the whole year, and were significantly larger than interannual changes in the cold season (Table 1). For the ablation season, the magnitude of interannual variations in melt were similar to those for snowfall, and both were significantly larger than the interannual variations in sublimation (or evaporation) and refreezing. Melt and snowfall in the ablation season therefore make a similar contribution to controlling the annual mass balance, and to interannual fluctuations in the mass balance.
Although Xiao Anglong Glacier experienced a trend of decreasing mass balance, at a rate of $-6.4 \mathrm{~mm}$ w.e. $\mathrm{yr}^{-1}(p<$ 0.05 , via linear regression) throughout the study period, there was pronounced decadal variability (Fig. 4a). The different mass loss rates show that the annual glacier-wide mass balance was positive in most years during 1968-90, with a mean value of $83 \pm 185 \mathrm{~mm}$ w.e. $\mathrm{yr}^{-1}$, and that most annual mass balances became negative during 1991-2012, with a mean value of $-210 \pm$ $185 \mathrm{~mm}$ w.e. $\mathrm{yr}^{-1}$. The annual mass loss rate reduced and the annual mass balance in some years became positive during 2013-19, when the mean mass balance was $-10 \pm 185 \mathrm{~mm}$ w.e. $\mathrm{yr}^{-1}$. In addition, the interannual mass balance variability was smallest during 1962-90 (the standard deviation was $131 \mathrm{~mm}$ w.e.) and was largest during 2013-19 (the standard deviation was $247 \mathrm{~mm}$ w.e.). According to Student's $t$ tests, the $p$ values (probability values) for 1968-90 and 1991-2012, and for 19912012 and 2013-19 were less than 0.001, suggesting that interdecadal changes in mass balance were significant during 1968-2019.

Such interdecadal changes in mass balance for Xiao Anglong Glacier are similar to changes seen for Naimona'nyi Glacier and Stok Glacier (Fig. 1a), both of which are located on the TP (Fig. 4c). And these changes are also similar to changes found for Chhota Shigri Glacier (Fig. 1a), on the southern slope of the western Himalayas, except for the period 1990-99 (Fig. 4c). We also compared regional changes in glacier mass balance over recent decades for the region surrounding Xiao Anglong Glacier (Fig. S1). The mean mass balance was 63 and $213 \mathrm{~mm}$ w.e. $\mathrm{yr}^{-1}$ higher during 2000-18 than during 1976-99 for the western Kunlun Mountains and the northern Qiangtang Plateau (Zhang

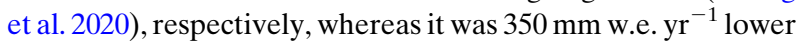
during 2000-16 than during 1975-2000 for both the SpitiLahaul and West Nepal regions (Table S1A in Maurer et al. 2019). Xiao Anglong Glacier is located between the western Kunlun Mountains/northern Qiangtang Plateau and the SpitiLahaul/West Nepal regions. The differences in mean mass balance $\left(-148 \pm 185 \mathrm{~mm}\right.$ w.e. $\mathrm{yr}^{-1}$ ) between $2000-18$ and 1973-99 for Xiao Anglong Glacier was larger than that for glaciers in the Spiti-Lahaul and West Nepal regions, and was smaller than that for glaciers on the northern Qiangtang Plateau and in the western Kunlun Mountains. This further illustrates that our reconstructions are reasonable.

\section{Discussion}

\section{a. Climate variables controlling the interannual variability} of the mass balance on Xiao Anglong Glacier

In 1968-2019, there was a significant warming trend in $T_{a}$ in the ablation season, and a slightly decreasing trend in precipitation for the whole balance year and for the ablation season (Fig. S6). It is thus necessary to remove the trends from these climate factors before analyzing which factors drive the interannual mass balance variability using the correlation analysis method. After detrending, the annual mass balance was weakly correlated with ablation-season $T_{a}(r=-0.26, p<0.05)$ due to small effect of ablation-season $T_{a}$ on snow accumulation and melt on interannual time scales. Note that $T_{a}$ was not 
significantly correlated with snowfall ( $r=0.11, p=0.79$ after detrending) due to almost all the precipitation falling as snow in the ablation season (Table 1). In addition, for the ablation season, $T_{a}$ was not significantly correlated with albedo $(r=$ $0.08, p=0.59$ after detrending), indicating a small influence of $T_{a}$ on interannual variability in $Q_{M}$ because interannual variability in $Q_{M}$ was driven by albedo. After detrending, the annual mass balance is strongly correlated to annual precipitation $(r=0.86, p<0.01)$ and to ablation-season precipitation $(r=$ $0.84, p<0.01)$. The ablation-season precipitation can affect the interannual mass balance variability through controlling snow accumulation processes and changing melt processes (Zhu et al. 2021). Furthermore, after detrending, the relationships among annual mass balance, monthly precipitation, and monthly $T_{a}$ were analyzed (Table S4). The annual mass balance has significant correlations with precipitation and $T_{a}$ in July and August. And correlation coefficients between monthly precipitation and annual mass balance were higher than those between monthly $T_{a}$ and annual mass balance. Above all, interannual mass balance variability was influenced more by ablation-season precipitation when compared to ablation-season $T_{a}$.

To examine the influence of regional climate drivers on mass changes for Xiao Anglong Glacier, we analyzed spatial correlation patterns between the annual mass balance and CRU ablation-season precipitation, and between the annual mass balance and CRU ablation-season $T_{a}$, for 1968-2019 (Fig. S7). A statistically significant $(p<0.05)$ positive correlation between annual mass balance and ablation-season precipitation is concentrated in western Tibet, and there are weak correlations between annual mass balance and ablation-season $T_{a}$ in a few regions in central Asia. Therefore, ablation-season precipitation was a primary driver for fluctuations in annual glacier mass balance in western Tibet, because ablation-season precipitation greatly influences the accumulation and ablation processes.

\section{b. The possible relationship of interannual mass balance variability with atmospheric circulation}

Regional changes in glacier mass balance are always linked to large-scale atmospheric circulation, through changing $T_{a}$ and precipitation (Mölg et al. 2014; Yao et al. 2012). The differences between contrasting composites have been used to explore the influence of atmospheric circulation on climate variability (e.g., Ding and Wang 2005; Mölg et al. 2017). As stated in section $3 \mathrm{~b}$, the ablation-season mass balance determined the annual mass balance on interannual time scales. To analyze the influence of regional climate and atmospheric circulation on changes to glacier mass balance, we divided the time series of ablation-season mass balance into phases of distinctly positive and negative mass balance, based on the standardized ablation-season mass balance (Fig. 4b). Years for which the standardized ablation-season mass balance was larger than 0.75 were classed as distinctly positive mass balance phases; those when the standardized ablation-season mass balance was smaller than -0.75 were classed as distinctly negative mass balance phases. The climate conditions that lead to negative balance can be found from the difference between these contrasting composites, the negative mass balance phases minus the positive mass balance phases. From a regional
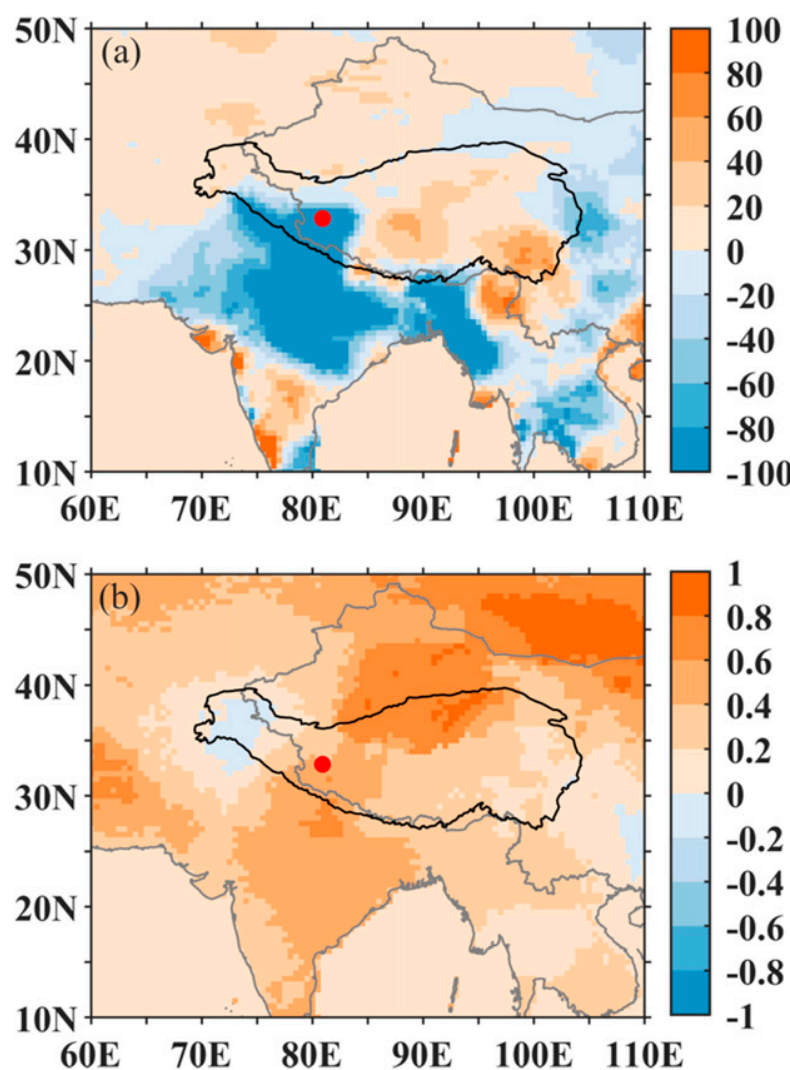

FIG. 5. Differences between positive and negative mass balance phases, 1968-2019 for (a) ablation-season precipitation (mm) and (b) ablation-season air temperature $\left({ }^{\circ} \mathrm{C}\right)$. The air temperature and precipitation fields were from CRU. Values for meteorological variables in the negative mass balance phases, minus their values in the positive mass balance phases. The black line denotes the outline of the Tibetan Plateau. The red dot points the location of Xiao Anglong Glacier.

perspective, ablation-season $T_{a}$ was higher, and ablationseason precipitation was lower, during negative mass balance phases than during positive mass balance phases in western Tibet (Fig. 5), which means that this method of mass balance classification can be used to analyze the influence of regional climate on mass balance variations in western Tibet.

To assess the influence of atmospheric circulation on changes in glacier mass balance, the differences in ablation-season geopotential height and wind fields at $500 \mathrm{hPa}$ between the positive and negative mass balance phases were analyzed for 1968-2019 (Fig. 6). The mean elevation of the TP area is above $4500 \mathrm{~m}$ and the $500-\mathrm{hPa}$ level is just above the surface of the TP. Geopotential height/wind fields at 500-hPa levels are routinely used to discern the vertical extent/configuration of tropospheric pressure systems, which provide valuable clues regarding the relationship between atmospheric circulation and air temperature (and/or precipitation) on the TP (Forsythe et al. 2017; Yang et al. 2016; Zhang et al. 2018). There are two centers of anomalies in the atmospheric circulation: a lower geopotential height and anticyclonic anomaly for $500 \mathrm{hPa}$ at higher latitudes over Russia, and a higher geopotential height and 


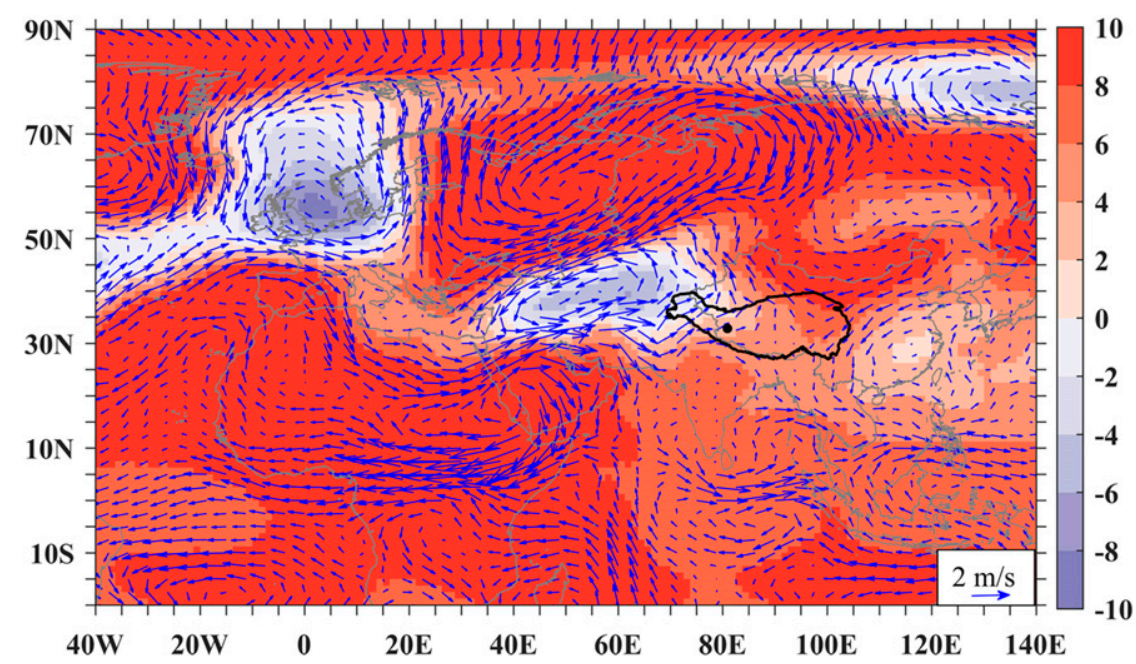

FIG. 6. Differences in ablation-season geopotential heights (gpm) and wind fields at $500 \mathrm{hPa}$ between the negative and positive mass balance phases for 1968-2019. Difference: negative mass balance phase values minus positive mass balance phase values. The black line denotes the outline of the Tibetan Plateau. The black dot points the location of Xiao Anglong Glacier.

cyclonic anomaly over central Asia (Fig. 6). This atmospheric circulation pattern was defined as strong westerly phases or a southward shift of the westerlies in Mölg et al. (2017). Under such atmospheric circulation pattern, a strong northerly wind anomaly extended from the high latitudes to the subtropics, and the southern flank of the anomalous cyclonic circulation enhanced westerlies at $30^{\circ}-35^{\circ} \mathrm{N}$, which contains the northern Indian continent and western Tibet (Fig. 6). These enhanced westerlies at $30^{\circ}-35^{\circ} \mathrm{N}$ favor the advection of dry air to northwest India and western Tibet, which can decrease convective instability over the Indian subcontinent and western Tibet (Mölg et al. 2017; Krishnan et al. 2009). The suppressed convection may in turn weaken the monsoon flow, which generates drought-like conditions over India (Krishnan et al. 2009). We also analyzed the differences in ablation-season geopotential height and wind fields at $300 \mathrm{hPa}$ between the positive and negative mass balance phases for 1968-2019 (Fig. S8) and found that the results were similar.

In addition, Fig. 6 shows an anticyclonic anomaly over central India and an anomalous northwesterly flow over central-eastern India. And the anomalous northwesterly wind over central-eastern India is obvious at 550-900 hPa (an example for wind fields at $600 \mathrm{hPa}$ is listed in Fig. S9). Such anomalous northwesterly flow reduces moist transport over western Tibet from central-eastern India through "up and over" transport ("intrusive") and upslope transport ("nonintrusive") (Dong et al. 2016). Thus, a southward shift in the middle and upper tropospheric westerlies contributes to low ablation-season precipitation in western Tibet (Fig. 6), which is conducive to a negative mass balance. However, the change in ablation-season $T_{a}$ found in this work (Fig. 5b) is different from that found in Mölg et al. (2017), under similar atmospheric circulation, perhaps because the change in ablation-season $T_{a}$ was influenced more by global warming than by cold-air advection from the intrusion of the westerlies.
Since the interannual variability in mass balance was controlled by variations in ablation-season precipitation, we examined the correlations between the regionally averaged CRU precipitation in the selected region and the 500-hPa geopotential height and wind fields during the ablation season further. This allowed us to assess how large-scale atmospheric circulation may influence glacier mass changes in western Tibet. Through consideration of the significant spatial differences in precipitation seasonality across western Tibet and the surrounding regions (Maussion et al. 2014), a rectangular region $\left(30.5-34.5^{\circ} \mathrm{N}, 80^{\circ}-85^{\circ} \mathrm{E}\right)$ was selected to represent western Tibet. After detrending, the correlation coefficients between the regionally averaged CRU ablation-season precipitation and the reconstructed ablation-season precipitation $(r=0.87$, $p<0.01$ ), and between regionally averaged CRU ablationseason precipitation and the annual mass balance $(r=0.77, p<$ 0.01 ), are relatively high. This indicates that the regionally averaged CRU ablation-season precipitation in the selected region reflects changes in ablation-season precipitation in western Tibet, and so can be used to analyze glacier mass changes in western Tibet. Next, we checked correlation patterns between the 500-hPa geopotential height and wind fields and regionally averaged CRU ablation-season precipitation. The higher regional ablation-season precipitation in western Tibet corresponds to an anomalous cyclone over central India and high-latitude Russia, and to an anomalous anticyclone over central Asia (Fig. 7 and Fig. S10). The anomalous cyclone over central India could be related to the intensified convection over the Indian subcontinent, which increased southerly winds over central-eastern India. This leads to an increase in moisture transported from the centraleastern India to western Tibet through upslope transport (more frequent but less efficient), and through up-and-over transport (less frequent but more efficient) (Dong et al. 2016). 


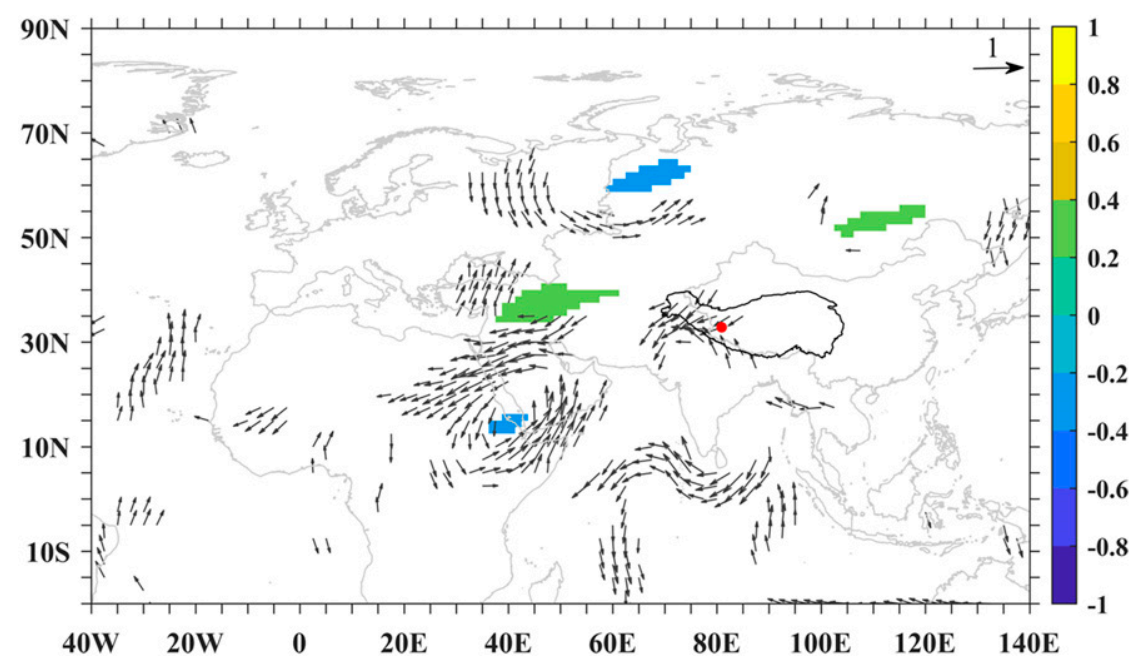

FIG. 7. Patterns for the correlations between the 500-hPa geopotential height and wind fields, and regionally averaged CRU precipitation during the ablation season for 1968-2019. Correlations for the 500-hPa geopotential height fields and wind fields (either zonal or meridional wind speed) are plotted only when they are significant (above the 0.05 level). Data are all detrended. The correlation length scale is shown in the upper right corner of panels. The 500-hPa geopotential heights and wind speed fields are from JRA-55. The black line denotes the outline of the Tibetan Plateau. The red dot denotes the location of Xiao Anglong Glacier.

The wind fields in Fig. 7 and Fig. S10 herein are a little different from those in Fig. 6 in Dong et al. (2016), and anomalous southerly wind anomalies in this study do not cover western Tibet. This may be because the frequency for the upand-over transport is very low (Dong et al. 2016), and upslope transport appears more clearly in Fig. 7 and Fig. S10. However, both the upslope transport and the up-and-over transport are conducive to higher precipitation over the southwestern TP (containing western Tibet) (Dong et al. 2016). At the same time, an easterly wind anomaly occurred in western Tibet (Fig. 7 and Fig. S10), suggesting that the westerlies were reduced (Mölg et al. 2017) and local convection can be easily enhanced over western Tibet, as can be indicated in the conclusions in Krishnan et al. (2009). These processes resulted in higher ablation-season precipitation and higher annual mass balance for glaciers in western Tibet.

The change in the position of the upper-tropospheric westerly jet corresponds well with the northward or southward shift of the middle and upper tropospheric westerlies because the westerly jet variability is a consequence of the stationary wave structure of the midlatitude westerlies (Mölg et al. 2017). In other words, the subtropical westerly jet position index (SWJPI) can be used to indicate the state of the westerlies. The SWJPI is defined as the area-averaged zonal wind at $200 \mathrm{hPa}$ in a southern region $\left(30^{\circ}-45^{\circ} \mathrm{N}, 50^{\circ}-80^{\circ} \mathrm{E}\right)$ minus the one in a northern region $\left(45^{\circ}-60^{\circ} \mathrm{N}, 50^{\circ}-80^{\circ} \mathrm{E}\right.$ ) (Zhao et al. 2014), which is calculated based on JRA-55 data. Positive deviations in the normalized time series of such index indicate a more southerly jet position (Mölg et al. 2017; Zhao et al. 2014). The ablation-season SWJPI is negatively correlated with the annual mass balance (with detrending, $r=-0.4, p<0.005$; Fig. 8a), the reconstructed ablation-season precipitation (with detrending, $r=-0.43, p<0.005)$, and regionally averaged CRU ablation-season precipitation in western Tibet (with detrending, $r=-0.33, p<0.05)$; that is, the annual mass balance and ablation-season precipitation increases when the ablationseason subtropical westerly jet moves northward. JulyAugust mass balance was the largest contributor to influence the interannual mass balance variability when compared to other months (Table S4). We further analyze the relationship between the July-August SWJPI index and annual mass balance (Fig. 8b). The July-August SWJPI also presents a negative correlation with annual mass balance (with detrending,

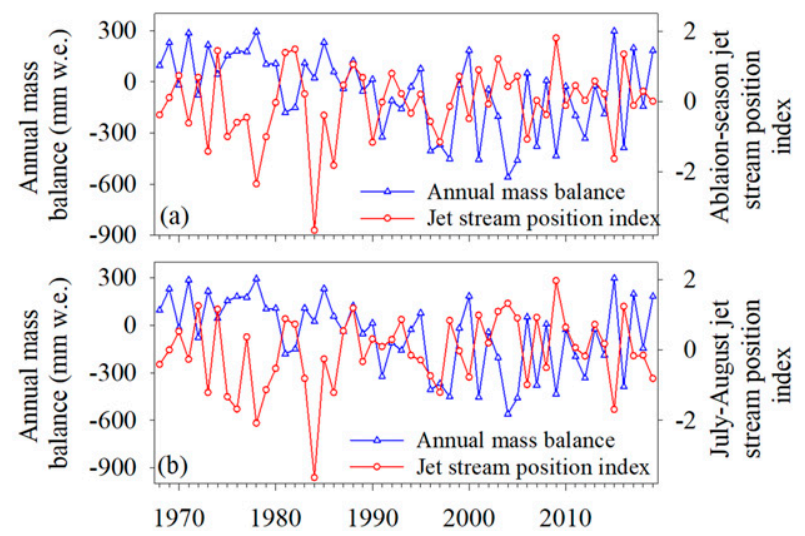

FIG. 8. Comparisons of annual mass balance (a) vs ablationseason subtropical westerly jet position index and (b) vs JulyAugust subtropical westerly jet position index during 1968-2019. The subtropical westerly jet position index is calculated from JRA55. The year on the $x$ axis indicates the balance year. 
TABLE 2. Mean seasonal meteorological variables, energy fluxes ( $\mathrm{W} \mathrm{m}^{-2}$ ), and mass fluxes ( $\mathrm{mm}$ w.e.) in different periods for 1968-2019.

\begin{tabular}{llccc}
\hline \hline Season & \multicolumn{1}{c}{ Item } & $1968-90$ & $1991-2012$ & $2013-19$ \\
\hline Cold & $T_{a}\left({ }^{\circ} \mathrm{C}\right)$ & -11.7 & -10.4 & -9.7 \\
Ablation & & 3.5 & 4.6 & 5 \\
Annual & & -6.6 & -5.4 & -4.8 \\
Ablation & RH $(\%)$ & 58 & 57 & 53 \\
Cold & $P(\mathrm{~mm})$ & 25.4 & 24.6 & 20.7 \\
Ablation & & 132.7 & 103.1 & 172.1 \\
Annual & & 158.1 & 127.7 & 192.7 \\
Annual & Mass balance & 83 & -210 & -10 \\
Cold & & -47 & -45 & -76 \\
Ablation & & 130 & -165 & 66 \\
Ablation & Snowfall & 252 & 197 & 330 \\
& Refreezing & 46 & 96 & 89 \\
& Sublimation & -66 & -87 & -96 \\
& Melt & -102 & -371 & -257 \\
& $S_{\text {in }}$ & 314 & 313 & 304 \\
& Albedo & 0.75 & 0.7 & 0.71 \\
& $S_{\text {out }}$ & -237 & -219 & -215 \\
& $S_{\text {net }}$ & 77 & 94 & 89 \\
& $L_{\text {in }}$ & 231 & 236 & 238 \\
& $L_{\text {out }}$ & -291 & -297 & -298 \\
& $L_{\text {net }}$ & -60 & -61 & -60 \\
& $H_{\text {sen }}$ & 5 & 2 & 4 \\
& $H_{\text {lat }}$ & -18 & -22 & -25 \\
& $Q_{G}$ & -1 & -1 & 0 \\
& $Q_{m}$ & 3 & 12 & 8 \\
\hline
\end{tabular}

$r=-0.51, p<0.005)$ due to the influence of the jet on JulyAugust precipitation, which has a large impact on interannual variability in mass balance. There are strong relationships between July-August SWJPI and the reconstructed JulyAugust precipitation (with detrending, $r=-0.52, p<0.005$ ), between the reconstructed July-August SWJPI and regionally averaged CRU July-August precipitation in western Tibet (with detrending, $r=-0.44, p<0.005$ ), and between July-August precipitation and annual mass balance (with detrending, $r=-0.82, p<0.005)$. Above all, changes in midlatitude westerly circulation may have resulted in changes to the glacier mass balance in western Tibet through changing precipitation in the ablation season.

\section{c. The interdecadal changes in the mass balance for Xiao Anglong Glacier and possible relationship with climate variables}

To understand the factors driving the interdecadal changes in mass balance for Xiao Anglong Glacier, we divided the 52 years of the study period into three periods. The mean annual mass balance for 1968-2019 was close to zero balance, and thus we took this whole period as the background reference period (Table 1). The mean $T_{a}$ in the ablation season was about $0.7^{\circ} \mathrm{C}$ lower, and mean precipitation in the ablation season was only around $7.2 \mathrm{~mm}$ less (equal to $5 \%$ of the mean ablation-season precipitation for 1968-90) during 1968-90 than during 1968-2019. Thus, a decrease in ablation-season $T_{a}$, relative to $1968-2019$, was the main cause for the positive mass balance in 1968-90 since this caused a decrease in $L_{\text {in }}$, and a reduction in albedo and melt energy in the ablation season (Tables 1 and 2). The mean $T_{a}$ in the ablation season was about $0.4^{\circ} \mathrm{C}$ higher, and mean precipitation in the ablation season was around $22.4 \mathrm{~mm}$ less (equal to $22 \%$ of the mean ablation-season precipitation for 1991-2012) during 1991-2012 than during 1968-2019. According to the mass balance sensitivity test (Zhu et al. 2020), the changes in mass balance were 83 and $64 \mathrm{~mm}$ w.e. $\mathrm{yr}^{-1}$, when precipitation and $T_{a}$ in the ablation season were increased by $22 \%$ and $0.4^{\circ} \mathrm{C}$, respectively. Thus, both an increase in $T_{a}$ and a decrease in precipitation in the ablation season contribute to the stronger mass loss and lower accumulation in 1991-2012, by increasing $L_{\text {in }}$, reducing albedo and snowfall and enhancing melt in the ablation season, relative to 1968-2019 (Tables 1 and 2). The mean $T_{a}$ and precipitation in the ablation season were higher in 2010-19 than in the other two periods. Higher accumulation, from higher precipitation in the ablation season, compensated for the greater mass loss that was driven by the higher $T_{a}$ and $L_{\mathrm{in}}$ in the ablation season. This resulted in a reduced in mass loss during 2013-19 than during 1968-2019. The influence of $T_{a}$ on changes in mass balance on interdecadal time scales was stronger than that on interannual time scales, because of the increased ablation-season $T_{a}$ variability (or warming trend) and reduced ablation-season precipitation variability on interdecadal time scales (text S1). Above all, interdecadal changes in mass balance for Xiao Anglong Glacier shows a slight mass gain during 1968-90, a moderate mass loss for 1991-2012, and a slowdown in mass loss in 201319 , which was related to the magnitudes of the variations in both precipitation and $T_{a}$ in the ablation season.

\section{Conclusions}

The long-term annual mass balance (1968-2019) for Xiao Anglong Glacier in western Tibet was reconstructed using an EMB model, driven by available meteorological records for sites near the glacier. The results show that Xiao Anglong Glacier is close to a balanced condition, with an average value of $-53 \pm 185 \mathrm{~mm}$ w.e. $\mathrm{yr}^{-1}$ during $1968-$ 2019. It is a consistent widespread phenomenon for glaciers in the Anglong region. Ablation-season melt and snowfall dominate the interannual mass balance variability. Compared to ablation-season $T_{a}$, ablation-season precipitation was the more important controlling factor for interannual variability in the mass balance, through changing snow accumulation and melt processes.

Further analysis suggests that changes in midlatitude westerly circulation could drive changes in glacier mass balance in western Tibet through changing precipitation in the ablation season. When there has been a southward shift of the middle and upper tropospheric westerlies and there is a strong northerly wind anomaly extending from the high latitudes to the subtropics, the westerly winds between $30^{\circ}$ and $35^{\circ} \mathrm{N}$ over northwest India and western Tibet become enhanced. The advection of dry air into northwest India and western Tibet decreases the convective instability over the Indian subcontinent and western Tibet, and also results in reduced advection 
of moisture from central-eastern India to western Tibet. These changes result in low ablation-season precipitation and low annual mass balance for glaciers in western Tibet. These processes are reversed in years with high ablation-season precipitation and high annual mass balance for glaciers in western Tibet. Last, mass balance on Xiao Anglong Glacier experienced a pronounced decadal variability, with a slight mass gain during 1968-90, a moderate mass loss for 1991-2012, and a slowdown in mass loss in 2013-19. Such decadal changes were associated with the variations in precipitation and $T_{a}$ during the ablation season. Given the large spatial differences in precipitation seasonality and amount (Maussion et al. 2014), more mass balance and meteorological measurements in different regions of the western TP are needed to fully map the spatial and temporal variability of glacier mass balance on the western TP.

Acknowledgments. This study is jointly funded by the Strategic Priority Research Program of Chinese Academy of Sciences (Grant XDA2006020102), the National Natural Science Foundation of China (Grants 41971092, 41771085, and 4191101270), the Second Tibetan Plateau Scientific Expedition and Research Program (2019QZKK0201), National Key Research and Development Project (2019YFC1509102), the National Science Foundation Paleo Perspectives on Climate Change (Award 1502919), and the China Postdoctoral Science Foundation (Grants 2018T110147 and 2017m611014). We sincerely thank Editor Dr. Shawn Marshall and the two anonymous reviewers for their helpful suggestions and comments. We also thank USGS for the SRTM DEM and Landsat images, and China Meteorological Administration for meteorological data used in this study. JRA-55 data and CRU data were obtained from https://jra.kishou.go.jp/JRA-55/index_en.html and https://crudata.uea.ac.uk/cru/data/hrg/, respectively.

\section{REFERENCES}

Anslow, F. S., S. Hostetler, W. R. Bidlake, and P. U. Clark, 2008: Distributed energy balance modeling of South Cascade Glacier, Washington and assessment of model uncertainty. J. Geophys. Res., 113, F02019, https://doi.org/ 10.1029/2007JF000850.

Azam, M. F., and S. Srivastava, 2020: Mass balance and runoff modelling of partially debris-covered Dokriani Glacier in monsoondominated Himalaya using ERA5 data since 1979. J. Hydrol., 590, 125432, https://doi.org/10.1016/j.jhydrol.2020.125432.

—_, P. Wagnon, C. Vincent, A. Ramanathan, A. Linda, and V. B. Singh, 2014: Reconstruction of the annual mass balance of Chhota Shigri glacier, Western Himalaya, India, since 1969. Ann. Glaciol., 55, 69-80, https://doi.org/10.3189/ 2014AoG66A104.

Bolch, T., T. Pieczonka, K. Mukherjee, and J. Shea, 2017: Glaciers in the Hunza Catchment (Karakoram) have been nearly in balance since the 1970s. Cryosphere, 11, 531-539, https:// doi.org/10.5194/tc-11-531-2017.

Brunt, D., 1932: Notes on radiation in the atmosphere. Quart. J. Roy. Meteor. Soc., 58, 389-420, https://doi.org/10.1002/ qj. 49705824704.

Chen, D., Y. Tian, T. Yao, and T. Ou, 2016: Satellite measurements reveal strong anisotropy in spatial coherence of climate variations over the Tibet Plateau. Sci. Rep., 6, 30304, https:// doi.org/10.1038/srep30304.
Chen, Y., L. Tian, J. Zong, D. Zhu, C. Wang, and S. Jin, 2021: Variation of the Large and Small Anglong Glaciers in the Ngari Prefecture, Tibet, China. J. Glaciol. Geocryol., 43, 14-23, https:// doi.org/10.7522/j.issn.1000-0240.2019.0001.

Cogley, J. G., 2005: Mass and energy balance of glaciers and ice sheets. Encyclopedia of Hydrological Sciences, M. G. Anderson and J. J. McDonnell, Eds., Wiley, 2555-2573, https://doi.org/10.1002/0470848944.hsa171.

Crawford, T. M., and C. E. Duchon, 1999: An improved parameterization for estimating effective atmospheric emissivity for use in calculating daytime downwelling longwave radiation. J. Appl. Meteor., 38, 474-480, https://doi.org/10.1175/15200450(1999)038<0474:AIPFEE > 2.0.CO;2.

Cuffey, K., and W. S. B. Paterson, 2010: The Physics of Glaciers. 4th ed. Elsevier, 693 pp.

Ding, Q., and B. Wang, 2005: Circumglobal teleconnection in the Northern Hemisphere summer. J. Climate, 18, 3483-3505, https://doi.org/10.1175/JCLI3473.1.

Dong, W., and Coauthors, 2016: Summer rainfall over the southwestern Tibetan Plateau controlled by deep convection over the Indian subcontinent. Nat. Commun., 7, 10925 , https://doi.org/ 10.1038/ncomms10925.

Farinotti, D., W. W. Immerzeel, R. J. de Kok, D. J. Quincey, and A. Dehecq, 2020: Manifestations and mechanisms of the Karakoram glacier anomaly. Nat. Geosci., 13, 8-16, https:// doi.org/10.1038/s41561-019-0513-5.

Forsythe, N., H. J. Fowler, X. Li, S. Blenkinsop, and D. Pritchard, 2017: Karakoram temperature and glacial melt driven by regional atmospheric circulation variability. Nat. Climate Change, 7, 664-670, https://doi.org/10.1038/nclimate3361.

Fujita, K., and Y. Ageta, 2000: Effect of summer accumulation on glacier mass balance on the Tibetan Plateau revealed by mass-balance model. J. Glaciol., 46, 244-252, https:// doi.org/10.3189/172756500781832945.

Gao, J., T. Yao, V. Masson-Delmotte, H. C. Steen-Larsen, and W. Wang, 2019: Collapsing glaciers threaten Asia's water supplies. Nature, 565, 19-21, https://doi.org/10.1038/d41586018-07838-4.

Harris, I., T. J. Osborn, P. Jones, and D. Lister, 2020: Version 4 of the CRU TS monthly high-resolution gridded multivariate climate dataset. Sci. Data, 7, 109, https://doi.org/10.1038/ s41597-020-0453-3.

Immerzeel, W. W., and Coauthors, 2020: Importance and vulnerability of the world's water towers. Nature, 577, 364-369, https://doi.org/10.1038/s41586-019-1822-y.

Kääb, A., and Coauthors, 2018: Massive collapse of two glaciers in western Tibet in 2016 after surge-like instability. Nat. Geosci., 11, 114-120, https://doi.org/10.1038/s41561-017-0039-7.

Kenzhebaev, R., M. Barandun, M. Kronenberg, Y. Chen, R. Usubaliev, and M. Hoelzle, 2017: Mass balance observations and reconstruction for Batysh Sook Glacier, Tien Shan, from 2004 to 2016. Cold Reg. Sci. Technol., 135, 7689, https://doi.org/10.1016/j.coldregions.2016.12.007.

Kobayashi, S., and Coauthors, 2015: The JRA-55 reanalysis: General specifications and basic characteristics. J. Meteor. Soc. Japan, 93, 5-48, https://doi.org/10.2151/jmsj.2015-001.

Krishnan, R., V. Kumar, M. Sugi, and J. Yoshimura, 2009: Internal feedbacks from monsoon-midlatitude interactions during droughts in the Indian summer monsoon. J. Atmos. Sci., 66, 553-578, https://doi.org/10.1175/2008JAS2723.1.

Mandal, A., and Coauthors, 2020: Understanding the interrelationships among mass balance, meteorology, discharge and surface velocity on Chhota Shigri Glacier over 2002-2019 
using in situ measurements. J. Glaciol., 66, 727-741, https:// doi.org/10.1017/jog.2020.42.

Maurer, J. M., J. M. Schaefer, S. Rupper, and A. Corley, 2019: Acceleration of ice loss across the Himalayas over the past 40 years. Sci. Adv., 5, eaav7 266, https://doi.org/10.1126/ sciadv.aav7266.

Maussion, F., D. Scherer, T. Mölg, E. Collier, J. Curio, and R. Finkelnburg, 2014: Precipitation seasonality and variability over the Tibetan Plateau as resolved by the High Asia reanalysis. J. Climate, 27, 1910-1927, https://doi.org/10.1175/ JCLI-D-13-00282.1.

Mölg, T., N. J. Cullen, D. R. Hardy, G. Kaser, and L. Klok, 2008: Mass balance of a slope glacier on Kilimanjaro and its sensitivity to climate. Int. J. Climatol., 28, 881-892, https://doi.org/ 10.1002/joc.1589.

— , F. Maussion, W. Yang, and D. Scherer, 2012: The footprint of Asian monsoon dynamics in the mass and energy balance of a Tibetan glacier. Cryosphere, 6, 1445-1461, https://doi.org/ 10.5194/tc-6-1445-2012.

— — - and D. Scherer, 2014: Mid-latitude westerlies as a driver of glacier variability in monsoonal High Asia. Nat. Climate Change, 4, 68-73, https://doi.org/10.1038/nclimate2055.

,-- E. Collier, J. C. Chiang, and D. Scherer, 2017: Prominent midlatitude circulation signature in High Asia's surface climate during monsoon. J. Geophys. Res., 122, $12702-$ 12 712, https://doi.org/10.1002/2017JD027414.

Möller, M., F. Obleitner, C. H. Reijmer, V. A. Pohjola, P. Głowacki, and J. Kohler, 2016: Adjustment of regional climate model output for modeling the climatic mass balance of all glaciers on Svalbard. J. Geophys. Res., 121, 5411-5429, https://doi.org/ 10.1002/2015JD024380.

Nie, Y., Q. Liu, J. Wang, Y. Zhang, Y. Sheng, and S. Liu, 2018: An inventory of historical glacial lake outburst floods in the Himalayas based on remote sensing observations and geomorphological analysis. Geomorphology, 308, 91-106, https:// doi.org/10.1016/j.geomorph.2018.02.002.

Oerlemans, J., 2005: Extracting a climate signal from 169 glacier records. Science, 308, 675-677, https://doi.org/ 10.1126/science.1107046.

—_, and W. H. Knap, 1998: A 1 year record of global radiation and albedo in the ablation zone of Morteratschgletscher, Switzerland. J. Glaciol., 44, 231-238, https://doi.org/10.1017/ S0022143000002574.

Ragettli, S., F. Pellicciotti, R. Bordoy, and W. W. Immerzeel, 2013: Sources of uncertainty in modeling the glaciohydrological response of a Karakoram watershed to climate change. Water Resour. Res., 49, 6048-6066, https://doi.org/10.1002/wrcr.20450.

Rupper, S., and G. Roe, 2008: Glacier changes and regional climate: A mass and energy balance approach. J. Climate, 21, 5384-5401, https://doi.org/10.1175/2008JCLI2219.1.

Sakai, A., T. Nuimura, K. Fujita, S. Takenaka, H. Nagai, and D. Lamsal, 2015: Climate regime of Asian glaciers revealed by GAMDAM glacier inventory. Cryosphere, 9, 865-880, https:// doi.org/10.5194/tc-9-865-2015.

Shean, D. E., S. Bhushan, P. Montesano, D. R. Rounce, A. Arendt, and B. Osmanoglu, 2020: A systematic, regional assessment of High Mountain Asia Glacier mass balance. Front. Earth Sci., 7, 363, https://doi.org/10.3389/feart.2019.00363.

Shi, Y., and S. Liu, 2000: Estimation on the response of glaciers in China to the global warming in the 21st century. Chin. Sci. Bull., 45, 668-672, https://doi.org/10.1007/BF02886048.

Soheb, M., A. Ramanathan, T. Angchuk, A. Mandal, N. Kumar, and S. Lotus, 2020: Mass-balance observation, reconstruction and sensitivity of Stok glacier, Ladakh region, India, between 1978 and 2019. J. Glaciol., 66, 627-642, https://doi.org/10.1017/ jog.2020.34.

Thibert, E., R. Blanc, C. Vincent, and N. Eckert, 2008: Glaciological and volumetric mass-balance measurements: Error analysis over 51 years for Glacier de Sarennes, French Alps. J. Glaciol., 54, 522-532, https://doi.org/10.3189/002214308785837093.

Thompson, L. G., and Coauthors, 2018: Ice core records of climate variability on the Third Pole with emphasis on the Guliya ice cap, western Kunlun Mountains. Quat. Sci. Rev., 188, 1-14, https://doi.org/10.1016/j.quascirev.2018.03.003.

Tian, L., V. Masson-Delmotte, M. Stievenard, T. Yao, and J. Jouzel, 2001: Tibetan Plateau summer monsoon northward extent revealed by measurements of water stable isotopes. J. Geophys. Res., 106, 28 081-28 088, https://doi.org/10.1029/ 2001JD900186.

— J. Glaciol., 63, 194-197, https://doi.org/10.1017/jog.2016.122.

Van Pelt, W., and Coauthors, 2019: A long-term dataset of climatic mass balance, snow conditions, and runoff in Svalbard (19572018). Cryosphere, 13, 2259-2280, https://doi.org/10.5194/tc13-2259-2019.

Vincent, C., and Coauthors, 2013: Balanced conditions or slight mass gain of glaciers in the Lahaul and Spiti region (northern India, Himalaya) during the nineties preceded recent mass loss. Cryosphere, 7, 569-582, https://doi.org/ 10.5194/tc-7-569-2013.

Wagnon, P., and Coauthors, 2013: Seasonal and annual mass balances of Mera and Pokalde glaciers (Nepal Himalaya) since 2007. Cryosphere, 7, 1769-1786, https://doi.org/10.5194/tc-71769-2013.

Wang, N., J. He, J. Pu, X. Jiang, and Z. Jing, 2010: Variations in equilibrium line altitude of the Qiyi Glacier, Qilian Mountains, over the past 50 years. Chin. Sci. Bull., 55, 3810-3817, https:// doi.org/10.1007/s11434-010-4167-3.

Yang, K., J. He, W. Tang, J. Qin, and C. C. Cheng, 2010: On downward shortwave and longwave radiations over high altitude regions: Observation and modeling in the Tibetan Plateau. Agric. For. Meteor., 150, 38-46, https://doi.org/ 10.1016/j.agrformet.2009.08.004.

Yang, W., T. Yao, X. Guo, M. Zhu, S. Li, and D. B. Kattel, 2013: Mass balance of a maritime glacier on the southeast Tibetan Plateau and its climatic sensitivity. J. Geophys. Res., 118, 95799594, https://doi.org/10.1002/jgrd.50760.

— X. Xuo, T. Yao, M. Zhu, and Y. Wang, 2016: Recent accelerating mass loss of southeast Tibetan glaciers and the relationship with changes in macroscale atmospheric circulations. Climate Dyn., 47, 805-815, https://doi.org/10.1007/s00382-0152872-y.

Yao, T., and Coauthors, 2012: Different glacier status with atmospheric circulations in Tibetan Plateau and surroundings. Nat. Climate Change, 2, 663-667, https://doi.org/10.1038/nclimate1580. - and Coauthors, 2013: A review of climatic controls on $\delta^{18} \mathrm{O}$ in precipitation over the Tibetan Plateau: Observations and simulations. Rev. Geophys., 51, 525-548, https://doi.org/ 10.1002/rog.20023.

— risks on the Tibetan Plateau and surroundings. Chin. Sci. Bull., 64, 2770-2782, https://doi.org/10.1360/TB-2019-0246.

Ye, Q., J. Zong, L. Tian, J. G. Cogley, C. Song, and W. Guo, 2017: Glacier changes on the Tibetan Plateau derived from Landsat imagery: Mid-1970s to 2000-13. J. Glaciol., 63, 273-287, https://doi.org/10.1017/jog.2016.137. 
Zhang, G., W. Chen, G. Li, W. Yang, S. Yi, and W. Luo, 2020: Lake water and glacier mass gains in the northwestern Tibetan Plateau observed from multi-sensor remote sensing data: Implication of an enhanced hydrological cycle. Remote Sens. Environ., 237, 111 554, https://doi.org/10.1016/j.rse.2019.111554.

Zhang, H., Z. Li, and P. Zhou, 2021: Mass balance reconstruction for Shiyi Glacier in the Qilian Mountains, northeastern Tibetan Plateau, and its climatic drivers. Climate Dyn., 56, 969-984, https://doi.org/10.1007/s00382-020-05514-w.

Zhang, X., D. Chen, and T. Yao, 2018: Evaluation of circulationtype classifications with respect to temperature and precipitation variations in the central and eastern Tibetan Plateau. Int. J. Climatol., 38, 4938-4949, https://doi.org/10.1002/joc.5708.

Zhang, Y., Y. Hirabayashi, and S. Liu, 2012: Catchment-scale reconstruction of glacier mass balance using observations and global climate data: Case study of the Hailuogou catchment, south-eastern Tibetan Plateau. J. Hydrol., 444, 146-160, https://doi.org/10.1016/j.jhydrol.2012.04.014.

Zhao, H., W. Yang, T. Yao, L. Tian, and B. Xu, 2016: Dramatic mass loss in extreme high-elevation areas of a western Himalayan glacier: Observations and modeling. Sci. Rep., 6, 30706, https://doi.org/10.1038/srep30706.
Zhao, Y., and Coauthors, 2014: Impact of the middle and upper tropospheric cooling over central Asia on the summer rainfall in the Tarim Basin, China. J. Climate, 27, 4721-4732, https:// doi.org/10.1175/JCLI-D-13-00456.1.

Zhu, M., T. Yao, W. Yang, B. Xu, G. Wu, and X. Wang, 2018a: Differences in mass balance behavior for three glaciers from different climatic regions on the Tibetan Plateau. Climate Dyn., 50, 3457-3484, https://doi.org/10.1007/s00382017-3817-4.

,,,,,----- and Y. Xie, 2018b: Reconstruction of the mass balance of Muztag Ata No. 15 glacier, eastern Pamir, and its climatic drivers. J. Glaciol., 64, 259-274, https:// doi.org/10.1017/jog.2018.16.

, —_, Y. Xie, B. Xu, W. Yang, and S. Yang, 2020: Mass balance of Muji Glacier, northeastern Pamir, and its controlling climate factors. J. Hydrol., 590, 125447, https://doi.org/ 10.1016/j.jhydrol.2020.125447.

—, W. Yang, T. Yao, L. Tian, L. G. Thompson, and H. Zhao, 2021: The influence of key climate variables on mass balance of Naimona'nyi glacier on a north-facing slope in the western Himalayas. J. Geophys. Res., 126, e2020JD033956, https:// doi.org/10.1029/2020JD033956. 